\title{
Meeting of the Belgian Royal Society for Dermatology and Venereology
}

Editor: Prof. G.E. Piérard

March 12, 1999, Essene

\section{Contents}

Role of Iron in Dermatology

T. Simonart, J.P. Van Vooren,

D. Parent, M. Heenen, J.R. Boelaert

\section{Current Guidelines in}

\section{Melanoma Treatment}

L. Brochez, E. Verhaeghe, F. Sales,

V. Del Marmol, R. Deraemaecker,

K. Vossaert, J.M. Naeyaert

on behalf of the Melanoma Working

Group of Gent and Bordet . . . . 160

\section{An Appraisal of}

18-Fluorodeoxyglucose

Positron Emission

Tomography for Melanoma

\section{Staging}

P. Paquet, F. Henry, T. Belhocine,

R. Hustinx, F. Najjar,

C. Piérard-Franchimont, G.E. Piérard

P. Rigo
Medullary CD30+ T Cell

Lymphoma with

Eosinophilia and Hyper-IgE

Supervening during the

Relentless Course of

Pityriasis lichenoides

T. Hermanns-Lê, G.E. Piérard

Varicella-Zoster Virus

Vasculitis: A Case of

Recurrent Varicella without

Epidermal Involvement

I. Uhoda, C. Piérard-Franchimont,

G.E. Piérard

Pyoderma gangrenosum as an Early Revelator of Acute Leukemia

H. Beele, E. Verhaeghe, A. Stockman, A. Janssens, L. Noens, M.-L. Geerts,

I. Huys, J.-M. Naeyaert . . . . . . 176
Epithelioid Sarcoma:

A Puzzling Soft Tissue

Neoplasm in a Child

A. Theunis, J. André, D. Larsimont,

M. Song . . . . . . . . . . . . . 179

Comparative Anti-Dandruff

Efficacy between a Tar and a

Non-Tar Shampoo

C. Piérard-Franchimont, G.E. Piérard,

V. Vroome, G.C. Lin, Y. Appa .. . 181

The Boosted Oral Antifungal

Treatment for

Onychomycosis beyond the

Regular Itraconazole Pulse

Dosing Regimen

G.E. Piérard, C. Piérard-Franchimont,

J.E. Arrese . . . . . . . . . . . . . . 185 